\title{
Phytochemical Screening of Ant Plant Myrmecodia rumphii Becc.
}

\author{
Yenni Pintauli Pasaribu ${ }^{1}$, Yorinda Buyang ${ }^{2}$, Abraham \\ Laurens Rettob ${ }^{3}$ \\ Chemistry Education Department \\ Universitas Musamus \\ Merauke, Indonesia \\ 1pasaribu@unmus.ac.id, 2buyang@unmus.ac.id, \\ 3abraham@unmus.ac.id
}

\author{
Reinyelda Latuheru ${ }^{4}$ \\ Mechanical Engineering Department \\ Universitas Musamus \\ Merauke, Indonesia \\ ${ }^{4}$ latuheru@unmus.ac.id
}

\author{
Inggrid Marlissa ${ }^{5}$ \\ Mathematics Education Department \\ Universitas Musamus \\ Merauke Indonesia \\ 5inggrid_fkip@unmus.ac.id
}

\begin{abstract}
Ant plant Myrmecodia rumphii Becc. is an epiphytic plant that is widely used by local people as an herbal medicine to treat various diseases such as rheumatic and tumors. Methanol extract of $M$. rumphii Becc. showed high cytotoxicity against shrimp larvae Arthemia salina Leach and antioxidant potential as indicated by high inhibitory activity against DPPH radicals. In the present paper, we provide for the first time the results of phytochemical screening of ant plant $M$. rumphii Becc. Powder of $M$. rumphii Becc. was extracted with n-hexane, methylene chloride, ethyl acetate, and methanol then concentrated until concentrated extract was obtained. Test of compound groups was carried out qualitatively. The results showed that there were various metabolites of alkaloids, triterpenoids, steroids, flavonoids, phenolics, and tannins which were scattered in extracts with various levels of polarity. From these results it can be concluded that the plants of $M$. rumphii Becc's contains secondary metabolites which have interesting bioactivity.
\end{abstract} Becc.

Keywords-phytochemical; ant plant; Myrmecodia rumphii

\section{INTRODUCTION}

Medicinal plants have been known for a long time as bioactive art repositories that have the nature of therapeutic properties that varies and over a long period of time. This term is used to describe chemicals from plants that can improve the health status of an organism but not essential nutrients [1]. The vast array of therapeutic effects associated with medicinal plants includes anti-inflammatory, antiviral, antitumor, antimalarial, and analgesic. The most important of these bioactive constituent of plants are alkaloids, tannins, flavonoids and phenolic compounds.

Ant plant Myrmecodia rumphii Becc. is an epiphytic plant of Rubiaceae family that is widely used by local Papuans as an herbal medicine to treat various diseases such as rheumatic and tumors. Ant plant $M$. rumphii Becc. is one type of ant nest plant originating from Merauke especially in Tomer village. In general, the local Papuan community uses the ant nest $M$. rumphii Becc by drying it in the sun. The dried ant nests are boiled with water for further drinking as medicine.

Many antioxidant compounds can be found in fruits and vegetable including phenolics, carotenoids, anthocyanins, and tocopherols. Previous studies showed high antioxidant activity and cytotoxicity of methanol extracts of $M$. rumphii Beccs. Methanol fraction showed very high cytotoxicity with $\mathrm{LC}_{50}$ $0.48 \mu \mathrm{g} / \mathrm{ml}$. Ethyl acetate fraction showed very high antioxidant activity with $92.66 \%$ scavenging activity against DPPH radical [2].

Cytotoxicity activities of various plant extracts indicate the presence of active compounds. Faropyrum esculantum, $F$. tataricum, and $F$. mill contain active compounds, including polyphenols, alkaloids, terpenoids, steroids, and phenylpropanoid glycosides. One of the most active constituents of various Chinese herbal medicines is polyphenols which have pharmacological properties such as antibacterial, antiviral, anti-inflammation and antioxidants. Routine, one class of flavonoids, shows antioxidant activity [3]. Phytochemical screening of some Papua endemic plant show that they contain some secondary metabolite compound. Metanol extract of Piper methysticum G. Forst, Xanthosthemon novaguineense Valet, and Macaranga aleuritoides F. Muell show the presence of secondary metabolite, i.e. alkaloid, flavonoid, tannins, and saponins [4].

Various plant species from the Rubiaceae family produce various active compounds. The Uncaria genus is one of the medicinal natural products, especially alkaloids and triterpenes. The recognized alkaloids compound in Uncaria are mitraphylline, which has been isolated from 20 of 34 species of Uncaria. Besides, another alkaloid were isolated from 18 species of Uncaria, i.e. rhynchophylline, isomitraphylline, 
isorhynchophylline. Pentacyclic triterpenoids from Uncaria were ursane-type, includes cytotoxic phenolic acid esters. In addition, various flavonoid and coumarin compounds have been isolated [5]. Phytochemical screening of Morinda morindoides leaf extract (Morinda genus) showed the presence of flavonoids, alkaloids, polyphenols, tannins, saponins, quinones and sterols [6]. Adina trichotoma Zoll. \& Moritzi. Folium contains alkaloids, terpenoids, glycoside, anthraquinone; Amaracarpus pubescens Blume. Folium contains alkaloids, flavonoids, terpenoids, glycoside, anthraquinone; Canthium glabrum Blume. Folium contains alkaloids, flavonoids, terpenoids, tannin, glycoside, anthraquinone; Chiococca javanica Blume. Folium contains alkaloids, flavonoids, terpenoids, tannins, glycoside, anthraquinone; Nauclea calycina (Batrl.ex DC.) Merr. Folium contains alkaloids, tannins, glycoside; Nauclea calycina (Batrl.ex DC.) Merr. Cortex contains flavonoids, terpenoids, tannins, glycoside, anthraquinone; Posoqueria latifolia (Lam.) Roem. Schult. Folium contains terpenoids, tannins, glycosides [7]. Leaf extract of Borreriaverticillta Linn shows the content of triterpenoids, flavonoids, phenols, alkaloids, saponins, tannins, and glycoside [8].

Ant plant from the genus Hydnophytum and Myrmecodia contain various compounds that make them possess attractive bioactivity. Ant plants Hydnophytum formicarum Folium contains terpenoids, alkaloids, tannins, glycoside, and saponins, while $H$. formicarum Cortex contains flavonoids, alkaloids, terpenoids and glycoside compounds [7]. Terpenoids, alkaloids, and phenolics are also contained in ant plant Myrmecodia pendens [9]. Phytochemical screening results on the sarang semut of $M$. beccarii, Myrmecodia sp., and Hydnophytum sp. showed that the three species contained flavonoid, triterpenoid/steroid, and saponin compounds [10].

\section{MATERIAL AND METHOD}

The material used was M. rumphii Becc's ant nest plant. from Tomer Village. The components contained in the sarang semut extract were analyzed by their compounds by a color test with several reagents for terpenoids/steroids, alkaloids, flavonoids, tannins and saponins.

\section{A. Identification of terpenoids/steroids}

Identification of terpenoids and steroids was done by dissolving concentrated extracts of ant plant in $0.5 \mathrm{ml}$ of chloroform then adding $0.5 \mathrm{ml}$ of acetic anhydride and dripping mixture with $2 \mathrm{ml}$ of concentrated $\mathrm{H}_{2} \mathrm{SO}_{4}$ through the tube wall. Triterpenoid positive results in the Lieberman-Burchard reagent test gave a red color and positive steroid test gave a green color.

\section{B. Identification of alkaloids}

Identification of alkaloids was carried out by the Mayer, Wagner, and Dragendorf methods. A total of 0.5 grams of concentrated extract of sarang semut were dissolved in $1 \mathrm{ml}$ of $2 \mathrm{M} \mathrm{HCl}$ and $9 \mathrm{ml}$ of distilled water then heated for 2 minutes, cooled and then filtered. Filtrate was divided into 3 parts, each added with Mayer, Wagner, and Dragendorf reagents. The positive results of alkaloids in the Mayer test were characterized by the formation of white deposits. Positive results of alkaloids in Wagner test were characterized by the formation of light brown to yellow deposits. While the positive results of alkaloids in the Dragendorff test were characterized by the formation of light brown to yellow deposits.

\section{Identification of flavonoids}

Identification of flavonoids was carried out by dissolving concentrated extracts of sarang semut in hot methanol and adding 0.1 grams of $\mathrm{Mg}$ powder and 5 drops of concentrated $\mathrm{HCl}$. Positive results of flavonoid identification tests were using the Wilstater test indicated by the appearance of red, yellow or orange.

\section{Identification of phenolic}

Phenolic identification was carried out by adding concentrated extracts of sarang semut with $2 \mathrm{ml} \mathrm{FeCl} 310 \%$ solution. Positive results of phenolic identification were indicated by the appearance of green, red, purple, blue or black [11].

\section{E. Identification of tannins}

Identification of tannin was carried out by dissolving concentrated extracts of ant plant in $10 \mathrm{ml}$ of distilled water then filtered. The filtrate was added with 3 drops of $\mathrm{FeCl}_{3} 1 \%$. Positive results of tannin identification tests were using $1 \%$ $\mathrm{FeCl}_{3} 3$ solution in water giving a strong green, red, purple or black color.

\section{F. Identification of saponins}

Saponin identification was carried out by dissolving concentrated extracts of sarang semut in $10 \mathrm{ml}$ of hot water and then shaking them vigorously for 10 seconds. Identification of the presence of saponins was using the Forth test indicated by the formation of foam and can last no less than 10 minutes and was not lost after the addition of $2 \mathrm{M} \mathrm{HCl}$ [11].

\section{RESULT AND DISCUSSION}

TABLE I. RESULTS OF PHYTOCHEMICAL SCREENING ON M. RUMPHII

\begin{tabular}{|l|l|l|l|l|}
\hline \multirow{4}{*}{$\begin{array}{c}\text { Phytochemical } \\
\text { Test }\end{array}$} & \multicolumn{4}{|c|}{ BECC. ANT PLANT } \\
\cline { 2 - 5 } & methanol & $\begin{array}{c}\text { ethyl } \\
\text { acetate }\end{array}$ & $\begin{array}{c}\text { methylene } \\
\text { chloride }\end{array}$ & $\begin{array}{c}\text { n- } \\
\text { hexane }\end{array}$ \\
\hline $\begin{array}{l}\text { Triterpenoid } \\
\text { steroids }\end{array}$ & + & + & + & + \\
\hline Phenolic & + & + & + & + \\
\hline Tannin & + & - & - & - \\
\hline Saponin & - & - & - & - \\
\hline Flavonoids & + & + & + & + \\
\hline Alkaloids: & & & & - \\
\hline Mayer & + & - & - & - \\
\hline Wagner & + & - & - & - \\
\hline Dragendorf & + & - & - & \\
\hline
\end{tabular}

The results of the study in Table 1 show that M.rumphii Becc. contain various secondary metabolites, i.e. triterpenoid/steroid, secondary phenolic, flavonoid, alkaloid, and tannin secondary metabolites which are distributed in methanol, ethyl acetate, methylene chloride and n-hexane. 
Steroid/triterpenoid compounds, phenolics, and flavonoids are scattered in all levels of solvent polarity starting from nonpolar, semipolar, and polar while tannin and alkaloid compounds are only found in polar solvents. Thus it is understood that terpenoid, steroid, phenolic, and flavonoid compounds are polar, but some are semi-polar and non-polar.

Tannins are found in methanol extracts but are not present in ethyl acetate, methylene chloride, and hexane extracts. This shows that the tannin class compound found in the plants of $M$. rumphii Becc. Tannin compounds are included in the very polar and large molecules. Besides that, M. rumphii Becc, does not contain saponin compounds, characterized by the absence of foam that lasts long enough when the solution was shaken.

Alkaloid test uses 3 types of reactants, namely Mayer, Wagner, and Dragendorf reagents. The test results showed that the positive methanol extract contained alkaloids, while ethyl acetate, methylene chloride, and n-hexane extracts were negative. This result means that the alkaloids contained in the plants of $M$. rumphii Becc. is very polar and most likely contains quite a lot of polar groups. But other ant plants from Merauke Regency such as M.beccarii, Myrmecodia sp., and Hydnophytum sp. do not contain alkaloids [10] .

Content of triterpenoid/steroid and flavonoid compounds in the methanol extract of $M$. rumphii Becc. in line with the discovery of flavonoid and triterpenoid/steroid group compounds in methanol extract plants of $M$. beccarii, Myrmecodia sp., and Hydnophytum sp. [10]. The content of alkaloids and phenolic compounds in $M$. rumphii Becc. in line with the class of compounds contained in M. pendens while the presence of tannin class compounds is the same as $M$. becarii [9].

Phytochemical test results supported the results of previous studies that showed the antioxidant activity of ant plant $M$. rumphii Becc. which is very high [2]. Antioxidant activity is generally owned by phenolic and flavonoid compounds and some terpenoids, steroids, alkaloids, and tannins. Methanol and ethyl acetate extracts contain flavonoid and phenolic compounds, these results are in line with the high antioxidant activity of both extracts. Antioxidant activity of ant plants is related to hydroxyl groups found in flavonoid and phenolic compounds that can donate hydrogen atoms to neutralize DPPH free radicals. When a compound that can donate a hydrogen is mixed with DPPH solution, this free radical will be reduced to non-radical form with loss of violet color. The more hydroxyl groups, the more reduction reactions can occur with DPPH [12]. Ethyl acetate extract of $M$. rumphii Becc. showed inhibition of $92.66 \%$ and $91.58 \%$ of radical DPPH, respectively [2]. Reference [13] wrote that the ethyl acetate extract of $H$. formicarum Jack's ant nest. showed highest scavenging activity $(83.31 \%)$ with $\mathrm{IC}_{50} 8.40 \mu \mathrm{g} / \mathrm{ml}$.

Isolation of compounds in ethyl acetate extract of $H$. formicarum Jack produce flavonoid compounds isoliquiritigenin, butin, butein and protocatechualdehyde phenolic compounds thus it can be proposed that the antioxidant potential of ethyl acetate fraction of $H$. formicarum Jack comes from the presence of these compounds. With this analogy, it can be said that high antioxidant activity in plant extracts of $\mathrm{M}$. rumphii Becc. caused by phenolic compounds and flavonoids contained therein. Flavonoids are antioxidants that are very effective in repairing and protecting cell structures [14].

Cytotoxicity of methanol extract $M$. rumphii Becc. against A. salina Leach shrimp larvae was indicated by $\mathrm{LC}_{50} 0.48 \mu \mathrm{g} /$ $\mathrm{ml}$ (very toxic). This cytotoxicity is also affected by the presence of flavonoid compounds that inhibit the eating power of larvae and stomach poisoning. Larval digestive devices will be disrupted by the presence of these compounds. In addition, this compound inhibits the taste receptors in the mouth area of the larvae thus the larvae fail to get a taste stimulus. As a result the larvae fail to recognize the food thus the larvae die of starvation [15].

\section{CONCLUSION}

M. rumphii Becc. Sarang semut plants contain various compounds from triterpenoid, steroid, flavonoid, phenolic, alkaloid, and tannin groups which are scattered in various levels of polarity extracts ranging from n-hexane extract, methylene chloride, ethyl acetate, and methanol with high antioxidant and cytotoxicity activity.

\section{ACKNOWLEDGMENT}

We thank Musamus University for facilities and supports. This project and publication were supported by DIPA Musamus University.

\section{REFERENCES}

[1] H. Raina, G. Soni, N. Jauhari, N. Sharma, and N. Bharadvaja, "Phytochemical importance of medicinal plants as potential sources of anticancer agents," Turk. J. Botany, vol. 38, no. 6, pp. 1027-1035, 2014.

[2] Y.P. Pasaribu, Y. Buyang, I.D. Pallitin, T. Ersam, and Y.L. Nimah, "Preparation and antioxidant activity of methanol extract of myrmecodiarumphii becc," Indian J. Public Heal. Res. Dev., vol. 9, no. $1,2018$.

[3] J. Zhao, C. Yu, and C. Peng, "Fagopyrum Mill-A Review of Phytochemistry and Pharmacological Effects," vol. 123, no. Msmee, pp. 72-81, 2017.

[4] M.S. Lestari, T. Himawan, A.L. Abadi, and R. Retnowati, "Research article toxicity and phytochemistry test of methanol extract of several plants from papua using Brine Shrimp Lethality Test ( BSLT )," J. Chem. Pharm. Res., vol. 7, no. 4, pp. 866-872, 2015.

[5] M.E. Heitzman, C.C. Neto, E. Winiarz, A.J. Vaisberg, and G.B. Hammond, "Ethnobotany, phytochemistry and pharmacology of Uncaria (Rubiaceae)," Phytochemistry, vol. 66, no. 1, pp. 5-29, 2005.

[6] A.C.A. Touré, C. Bahi, K. Ouattara, J.A. Djama, "Phytochemical screening and in vitro antifungal activities of extracts of leaves of Morinda morindoides (Morinda, Rubiaceae)," J. Med. Plants Res., vol. 5, no. 31, pp. 6780-6786, 2011.

[7] B. Elya, K. Basah, A. Mun'Im, W. Yuliastuti, A. Bangun, and E. K. Septiana, "Screening of $\alpha$-glucosidase inhibitory activity from some plants of Apocynaceae, Clusiaceae, Euphorbiaceae, and Rubiaceae," $J$. Biomed. Biotechnol., vol. 2012, 2012.

[8] I.M.H. H.S.A. Gero, A. Ahmad, A.U. Zezi, "Evaluation of Antioxidant Activity of Leave Extract of Borreriaverticillta Linn (Rubiaceae)," $J$. Natura; Sci. Res., vol. 4, no. 9, pp. 31-38, 2014.

[9] M.U.T. Hertiani, E. Sasmito, Sumardi, "Preliminary Study on Immunomodulatory Effect of Sarang-Semut Tubers Myrmecodia 
tuberosa and Myrmecodia pendens," Online J. Biol. Sci., vol. 10, no. 3, pp. 136-141, 2010.

[10] S. Dirgantara, A.S.A.R.I. Nawawi, and D.A.N.M. Insanu, "Uji Aktivitas Antioksidan Tiga Spesies Tanaman Sarang Semut (Famili : Rubiaceae ) Asal Kabupaten Merauke , Papua,” vol. 5, no. April, pp. 10-14, 2013.

[11] R. Fahmi, "Uji Fitokimia Metabolit Sekunder: Metode Lapangan dan Laboratorium," 2000.

[12] P. Molyneux, "The use of the stable free radical diphenylpicrylhydrazyl (DPPH) for estimating antioxidant activity," Songklanakarin J. Sci. Technol., vol. 26, no. June 2003, pp. 211-219, 2004.
[13] V.P.S. Prachayasittikul, P. Buraparuangsang, A. Worachartcheewan, C. Isarankura-Na-Ayudha, S. Ruchirawat, "Antimicrobial and antioxidative activities of bioactive constituents from Hydnophytum formicarum Jack," Molecules, vol. 13, pp. 904-921, 2008.

[14] H. Roslizawaty, N.Y. Ramadani, Fakhrurrazi, "Antibacterial Activity of Ethanol's Extract and Stew of Ant Plant (Myrmecodia sp.) Against Bakteria Escherichia coli," J. Med. Vet., vol. 7, no. 2, pp. 91-94, 2013.

[15] M.P. Mardany, L.Y. Chrystomo, and A.K. Karim, "Skrining Fitokimia dan Uji Aktivitas Sitotoksik dari Tumbuhan Sarang Semut ( Myrmecodia beccarii Hook . f .) Asal Kabupaten Merauke," J. Biol. Рариа, vol. 8, no. 1, pp. 13-22, 2016. 